Article

\title{
Establishing Operational Norms for Labor Rights Standards Implementation in Low-Cost Apparel Production
}

\author{
Rejaul Hasan, Marguerite Moore and Robert Handfield *[D \\ Wilson College of Management, North Carolina State University, Raleigh, NC 27695, USA; \\ mhasan4@ncsu.edu (R.H.); mmmoore4@ncsu.edu (M.M.) \\ * Correspondence: robert_handfield@ncsu.edu
}

\begin{abstract}
Low-cost production has driven many global apparel brands and retailers to source apparel from less developed countries. However, low-cost apparel production is often accompanied by labor rights violations. A persistent pattern of labor rights violations exists in the global apparel supply chains, including minimum wage violations, unpaid overtime, forced overtime, worker abuse, restricting workers' unions, and many other violations. Research suggests that low-cost pressures restrict factory level resources, which often leads to labor rights violations in global apparel supply chains. To date, academics and practitioners remain unaware of the actual cost of implementing labor rights standards in factories. We sought to establish a baseline taxonomy of the fundamental cost-bearing activities required to provide a safe and ethical factory workplace. A Delphi survey was adopted to capture data from an expert group of experienced factory compliance auditors in Asian apparel production. The research provides practical insights for factory adoption of actions that can improve enforcement of multiple labor standards, as well as specific actions required to enforce unique requirements that arose in our analysis.
\end{abstract}

Citation: Hasan, R.; Moore, M.;

Handfield, R. Establishing

Operational Norms for Labor Rights

Standards Implementation in

Low-Cost Apparel Production.

Sustainability 2021, 13, 12120. https://

doi.org/10.3390/su132112120

Academic Editor: Franklin G. Mixon

Received: 26 September 2021

Accepted: 28 October 2021

Published: 2 November 2021

Publisher's Note: MDPI stays neutral with regard to jurisdictional claims in published maps and institutional affiliations.

Copyright: (c) 2021 by the authors. Licensee MDPI, Basel, Switzerland. This article is an open access article distributed under the terms and conditions of the Creative Commons Attribution (CC BY) license (https:// creativecommons.org/licenses/by/ $4.0 /)$.
Keywords: apparel; production; labor rights standards; Delphi; minimum cost; safe factory

\section{Introduction}

Potential impacts of sustainability on operations and supply chain management (OSCM) in the global business environment present both challenges and opportunities for stakeholders among diverse industries. Elkington (1998) first introduced the idea of a triple bottom line in an effort to articulate the inherent multi-dimensionality associated with the corporate pursuit of sustainability [1]. Through the triple bottom line concept, Elkington suggests that corporate social responsibility (CSR) must balance social, environmental and economic demands to effectively pursue an achievable sustainability strategy over the longterm. Elkington's original assertion that managing the triple bottom line poses one of the greatest challenges to corporations in the 21st century generated considerable discourse and inquiry among stakeholders engaged in global supply chain management [2,3]. Labor and human rights thus represent a core requirement of the three-legged stool for organizations to become more sustainable, by ensuring that social compliance with respect to humans in the global supply chain.

Despite considerable academic attention on the environmental impacts of OSCM, researchers call for ongoing empirical work that provides insight into the social dimensions of sustainability in supply chain management [3-5]. For instance, Zorzini et al. [6] suggest that the literature lacks adequate consideration of social sustainability among suppliers in developing countries, where risk of human exploitation is higher compared to developed countries. We seek to address this gap by identifying the core elements that require more in-depth assessment and measurement in suppliers within developing countries.

Köksal et al. [7] illustrate the importance of considering social impacts within the broader agenda of sustainable supply chain management (SSCM) in the labor-intensive global apparel industry, primarily concentrated within developing economies. These 
authors review empirical work published between 2005 and 2016 to establish the current state of knowledge applicable to social sustainability in textile and apparel supply chains. Their analysis underscores conflicting goals between upstream and downstream supply chain actors in textile and apparel supply chains. Powerful buyers seek cost minimization and short lead times from suppliers who are simultaneously expected to conform to various ambitious codes of conduct (COC) consists of ethical workplace standards. Lowcost apparel production countries such as Bangladesh clearly have a stronger economic incentive to pursue production contracts rather than administer social compliance policies in factories that operate under extreme productivity demands. Conversely, textile and apparel buyers continue to pursue cost and productivity advantages, though exposure to reputational risk for ethical missteps is unprecedentedly high in today's digital media environment $[8,9]$.

Within vulnerable labor-intensive production environments, researchers tend to focus on upstream supply chain management with a common goal of achieving socially responsible sourcing (SRS) practices. Zorzini et al. [6] underscore the importance of emphasizing social responsibility in labor-intensive sectors due to lack of transparency and difficulty of implementation in environments plagued by corruption and poor adherence to labor standards. As an outcome of their work, the researchers call for research that captures supplier perspectives among developing countries for insight into SRS that focuses on human interactions and labor conditions. Anner (2013) identified price squeezes as one of the key underlining reasons for poor labor conditions and persistent labor rights violations in apparel supply chains [10].

In an effort to provide fundamental managerial insight into socially responsible sourcing in apparel supply chains within developing economies, a baseline understanding of the requirements for providing these safeguards is needed. In our research, we sought to identify the fundamental resources required to establish baseline labor standards to guide social compliance across Bangladeshi apparel factories. Specifically, we sought insight into the following research question:

What are the fundamental cost-bearing activities required to provide the minimum set of labor rights standards in Bangladeshi apparel factories aligned with current social compliance standards?

This question is important, in that it establishes the foundational elements that represent the minimal baseline standards for assessing social compliance in low-cost apparel factories. The relative cost measures are also important, as brands need to be aware that there is indeed an increased cost associated with sustainable standards, and this awareness is important to justify the price increases that may be involved. The study employs a Delphi approach to capture the informed perspectives of active compliance auditors in the field. These auditors are considered experts in the research design and data collection, and were the focal point for informing the research question; we relied on a selected small group of experts because of their comprehensive understanding of social compliance in apparel factories. In addition to addressing the critical human labor foundations for SSCM, the study provides direct insight into the cost-bearing activities for adopting labor standards among active apparel factories. Our results establish an empirically derived foundation directly addressing the operational challenges associated with responsible apparel production. Ultimately, the findings provide a basis for understanding the underlying production costs of responsible apparel production developing country factories that are economically dependent on a growing apparel industry.

\section{Literature Review}

Empirical analyses of the cost-bearing operational activities required to ensure responsible labor practices among apparel factories are relatively limited. An Internal Labour Organization (ILO) Better Work paper highlighted several case studies and potential remedies for some of the labor rights compliance challenges in the apparel industry [11]. These papers discussed the lack of clarity around required actions to ensure compliance with 
labor rights standards at the factory level. For example, Brown et al. [12] mentioned that the actions instituted by factory management, which lead to desirable outcomes in the health and safety of the working environment, are unclear, and have begun initiating efforts to address the issues in Vietnam and Jordan. Further, the trade literature provides limited guidance for identifying costs associated with the provision of workplace safety or related labor protections. The emerging research relevant to labor standards implementation focuses on the provision of living wages [13] and is predominantly generated by sources outside of academia [14-17]. Mattioda et al. [18] as well as van der Velden and Vogtländer [19] develop conceptual efforts to associate cost with Social Life Cycle Assessment, which may inform labor rights costing in the future.

In the absence of direct evidence, we conducted a literature review which incorporated civil and corporate perspectives on labor standards adoption and implementation as a basis for contextual understanding. We considered the United Nation's (UN) International Labour Organization (ILO) labor standards, corporate codes of conduct, and the emergence of third-party monitoring within the apparel production environment. Extant research into the drivers of labor rights violations among apparel factories is also reviewed for potential insight into identifying responsible operational activities that apply directly to this supply chain.

\subsection{Labor Standards Adoption and Effectiveness}

The UN International Labour Organization (ILO) Conventions provides legally binding international treaties for the ratifying member states on child labor, forced labor, freedom of association, minimum wage, equal remuneration and discrimination [20]. Member countries who adhere to ILO standards are obligated to respect, promote, and realize the organization's fundamental conventions. Additionally, Organization for Economic Co-operation and Development (OECD) guidelines for business conduct provide practical support to enterprises for implementing due diligence around labor rights [21,22]. The United Nations (UN) Global Compact provides companies guidance through its principles on human rights with emphasis on areas including child labor, forced labor, non-discrimination and collective bargaining [23].

During the late 1990s, multinational corporations such as Nike, Wal-Mart and H\&M initiated efforts to develop voluntary codes of conduct (COC) to mitigate fallout from highly publicized labor violations among their global supply chains [24-26]. Corporate COCs are entirely voluntary and commonly based on ILO standards. The World Bank (2003) suggests a broad range of variance among COCs through a study of over 1000 corporations in a single year [27]. Locke (2007) finds a lack of efficacy-based COCs in Nike's internal audit data from 800 factories in 51 countries (1998-2005), which suggests that only 20 percent of the firms had improved compliance while 34 percent had reduced compliance [26]. However, COCs continue to be used as the primary mechanism for labor standards enforcement [26,28].

Growing public pressure for corporate social responsibility in global apparel supply chains has prompted interest in the United States and Europe to establish standardized codes of conduct and monitoring systems administered by objective third parties. Examples of third-party monitoring organizations in the apparel industry include: the Fair Labor Association (FLA), Social Accountability International (SAI) and Worldwide Responsible Apparel Production (WRAP), Ethical Trading Initiatives (ETI), Fair Wear Foundation (FWF) and the Worker Rights Consortium (WRC). Third party entities independently develop standards which conform to ILO guidance, and devise and implement monitoring systems for compliance to these standards $[10,24]$. A common outcome for entities who comply with a third-party monitoring organization is explicit recognition of compliance (i.e., certification) which can be awarded to different entities in the supply chain (e.g., brands and factories). 


\subsection{Labor Standard Violations}

Despite countries' explicit acceptance of ILO standards, corporations' voluntary COCs, and third-party systems to implement and monitor labor standards, worker rights violations prevail in global apparel supply chains. Examples of ongoing labor violations are noted in both the trade and academic literature. The ILO (2015) reported wage violations, forced overtime, false working hour records, unsafe working conditions and pressure against collective bargaining within global supply chains not specific to apparel [29].

Ross (2016) documents numerous labor rights violations that implicate established apparel brands, including: Wal-Mart, H\&M, Sears, C\&A, Gap, Kik, Dickies, and Li \& Fung, in his book focused on labor rights motivated by the Rana Plaza factory collapse, which is regarded as the worst industrial tragedy in the 200-year history of mass apparel manufacturing [30]. The recklessness in labor rights within the global apparel industry has reached the point where three of the four worst industrial disasters in history have occurred in the last decade [31]. Despite the recognition of these violations, there are few studies which specifically identify the minimal standards required to address such violations, and the increased costs of doing so.

\subsection{Drivers of Labor Standard Violations}

The persistence of labor standards violations in global apparel supply chains represents a compelling reason to better understand the weaknesses in existing mechanisms for standards enforcement at the factory level. The literature provides potential insight into the drivers of labor rights violations within the global context. Some of these drivers of violations include inadequate oversight, lack of transparency and continued downward price pressure among apparel importers. Researchers suggest that auditing systems are inherently ineffective due to the voluntary nature of implementation and compliance $[26,32,33]$. Likewise, researchers note the limitations of auditing practices for identifying labor rights violations in factories [34,35]. Further evidence supports this position by pointing out that both Tazreen Fashion in Bangladesh and Ali Enterpris in Pakistan passed audits shortly before disastrous factory fires kills hundreds of workers [31,36,37]. Nevertheless, factory audits remain as the primary mechanism for monitoring labor rights in apparel productions.

Toffel et al. [38] suggest that voluntary regulations are often less effective in countries with poor compliance with government regulations such as Bangladesh, India, and Pakistan. Though existing labor law and government regulations in Bangladesh are largely aligned with the ILO, these laws and policies are not regularly enforced. Research suggests that ten percent of the Bangladeshi Parliament owns apparel manufacturing businesses $[39,40]$. Given the power of these individuals in Bangladeshi society, the interests of business are more likely to be protected than those of factory workers [41].

Further, the government favors low-market prices to its competitive advantage in global apparel exporting, which impedes regulatory reformation in critical areas such as compensation (Anner 2018). Experts assert that lack of oversight in the Bangladeshi apparel industry likely encourages foreign direct investment (FDI) in the country among multinational corporations $[39,40,42,43]$. The government's failure to enforce industry regulations in Bangladesh creates an opening for additional stakeholder efforts to monitor labor rights in apparel factories, including private regulatory interventions initiated by global apparel brand, global unions, and multi-stakeholder initiatives. For example, the Bangladesh Accord and Alliance represent the two such initiatives implemented by interests in Western Europe and North America, respectively. Research suggests that the Accord, a binding agreement, ultimately improved building safety despite challenges associated with financing these efforts $[40,44]$. The same studies report little progress towards improving conditions impacted by systemic labor violations, including living wages, union formation, excessive overtime and unauthorized subcontracting.

Additional costs required at both the factory and the brand level represent an ongoing barrier for effective labor standards enforcement implementation among factories $[8,45]$. 
Stigzelius and Mark-Herbert (2009) demonstrate the financial burden to suppliers (i.e., factories) required for implementation of Social Accountability International (SA8000) standards, which required additional investment in wages, facility improvements, and audit administration [10]. There are already exist many artifacts related to the lack of understanding of how to quantify and measure human rights in the supply chain

Anner (2013) demonstrates the critical impact of price pressure on the incidence of labor violations [1]. This inquiry identified a 48 percent decrease in the real dollar price per square meter of U.S. apparel imports based on (Office of Textiles and Apparel) OTEXA data representing the top 20 exporters from 1989-2010. Anner noted that the Cingranelli and Richards CIRI labor rights scores decreased during the same period and worker wages remained flat or decreased between 2001 and 2010. Anner also demonstrates a departure from prior work that focuses primarily on factories as the source of violations [46,47]. He suggests that violations originate from the nature of business models commonly adopted by multinational brands seeking increasingly lower costs and are therefore identifiable and predictable. Locke [48] concurs with Anner by citing price pressure and short delivery schedules as drivers of factory compliance failures.

Another fundamental challenge in global apparel supply chains is the existing system for determining prices. Hasan et al. [49] report that the additional cost of compliance for an employer to provide workers with a living wage quadrupled from the factory door to the retail store due to the current customs and duty structure current apparel mark-up practices. The empirical data suggests that while a brand needs to pay an additional $\$ 0.32$ USD to comply with living wage requirements at the factory level for a basic t-shirt, the cost to the retailer totals $\$ 1.21$ USD due to the customs, duties and the subsequent markups. This price escalation presents an additional challenge for addressing the cost of labor rights compliance.

A recent post-pandemic apparel industry purchase practice report published by the Center for Global Workers' Rights and Worker Rights Consortium [50] reported that 65\% of buyers have demanded price cuts on new orders, which is beyond the buyers' typical year-over-year price reduction requests. This has resulted in an overwhelming $56 \%$ of suppliers being forced to accept orders priced below factory cost. The study demonstrated that during the post-pandemic period, there has been increased price pressure on apparel suppliers that is expected to create further labor rights violations in factories.

While prior research sheds light on the relationships between sourcing, production costs, and the labor rights violations in the production factory, a gap exists in understanding the specific cost-bearing activities required to implement labor rights standards in apparel production factories. Our intent is to understand the core costs associated with the cost of adopting a safe and compliant factory environment, as a basis for setting measurement constructs for different labor rights dimensions and related cost factors.

\section{Methodology}

The research employs a Delphi approach to identify unique factory interpretation, adoption, and implementation of labor standards among a panel of respondents identified as experts. The Delphi method is helpful for probing under-explored or emergent phenomena through building consensus among respondents with direct knowledge or experience in the focal area [51-54]. Data are collected and synthesized through an iterative survey process that elicits individual responses from experts and subsequently collates and reduces these responses based on subsequent rounds of data collection. An added benefit of this data collection approach is the ability to garner participation among subjects who are geographically dispersed [52,55]. Further, the contextual nature of labor standards implementation in factories requires a flexible and unbiased approach to capture a range of expert perspectives. 


\subsection{Expert Selection and Recruitment}

Active participation among motivated expert respondents is critical for effective Delphi administration [52]. Compliance auditors for large European retailers were the target expert population based on their extensive experience observing apparel factory labor conditions. Further, Bangladesh is the second largest apparel manufacturing economy in the world, accounting for more than 80 percent of the country's export revenue [56]. Further, the Bangladeshi industry is commonly cited for potential labor rights violations. A total of 26 auditors were asked to participate through an invitation letter and 15 agreed to respond, while the experts are employed by two leading global audit firms. Of the respondents, 6 of 15 are female (R1, R3, R8, R12, R13, R14); respondent R1 and R10 are audit managers, while the remainder of the respondents are auditors with significant auditing experience. Participants reported average audit work experiences of 9.5 years and typically conduct more than 100 yearly audits. All 15 participants were native Bangladeshi with extensive professional auditing experience in the country and other Asian countries (i.e., India, Sri Lanka, Thailand, China, and Vietnam). Additionally, respondents typically worked with first-tier factories that cater to global buyers.

\subsection{Data Collection}

Data collection was undertaken through three separate interactions between researchers and respondents. Secure survey software was used to collect data and provide informed consent to participants. Note that respondent identities were not shared among the expert cohort. Communication was directed solely among the researchers. The communication with the respondents occurred during the period from June to August 2018. The initial interactions with respondents, referred to as rounds, included online administration of two related questionnaires, administered with a two-week lapse between the first and second iteration. The final interaction invited respondents to review and react to a report compiled using inputs from the first two rounds (i.e., refined list of cost-bearing activities required to address minimum labor standards) to establish consensus [57].

The first survey round invited experts to provide a comprehensive list of the costbearing actions that factories should undertake to address eight unique core labor standards including: forced labor, child labor, compensation, discrimination, freedom of association, working hours, health and safety and disciplinary practices. Respondents were asked to list what they believed to be the minimum requirements, not necessarily what they observed in their direct compliance experiences. This was necessary to establish a consensus around minimum cost-bearing actions required to provide a safe and ethical workplace among apparel factories. The data generated in the first-round survey provided an inventory of cost-bearing activities that were organized based on frequency and topic and redistributed to respondents in the second-round survey.

Two weeks following initial data collection, a second questionnaire was administered to original respondents. This round of data collection presented participants with the master list of minimum cost-bearing actions generated in the previous round. They were invited to select actions from this list that they deemed as important for providing minimum compliance to each standard. They were also allowed to add additional cost-bearing actions that they did not consider during the first round. Participants were given one week to respond. Approximately two weeks later, respondents were provided with the refined list of prioritized actions for each labor standard determined in the second round of data collection. At this stage, respondents were asked to review the list of actions against each standard and make any final comments. Again, experts were given a one-week period to respond.

\subsection{Selection of Labor Standards}

The labor standards adopted for this study were derived from a review of the following inputs: The International Labour Organization (ILO), Worldwide Responsible Apparel Production (WRAP) certification program, Social Accountability International (SAI), the 
Fair Labor Association (FLA), the Ethical Trading Initiative (ETI), the Fair Wear Foundation (FWF), and corporate codes of conduct used by global brands including: H\&M, Nike, VF Corporation, and Decathlon. The labor standard terminology in this paper follows the definition provided by ILO.

\section{Results and Discussion}

The results of the Delphi study provide some important insights into the foundational elements and costs associated with minimal labor standards compliance. A total of 15 out of 26 invited experts agreed to participate in the study (58\%). Further attrition among the sample did not occur, as all respondents participated in subsequent data collection rounds. The experts indicated an average of 9.5 years of auditing experience (range: 5,17 ) in Asian apparel factories, including Bangladesh (Table 1). At the time of data collection, the majority of respondents served as compliance auditors $(n=13)$, while a small proportion served as compliance auditing managers $(n=2)$.

Table 1. Respondent Roles and Years of Experience.

\begin{tabular}{|c|c|c|}
\hline Professional Role & $\begin{array}{l}\text { Respondent } \\
\text { Identifier }\end{array}$ & Years of Experience \\
\hline \multirow{7}{*}{$\begin{array}{c}\text { Social Compliance Auditing } \\
\text { Manager }\end{array}$} & R1 & 17 \\
\hline & R10 & 12 \\
\hline & $\mathrm{R} 2$ & 15 \\
\hline & R3 & 12 \\
\hline & R4 & 8 \\
\hline & R5 & 9 \\
\hline & R6 & 9 \\
\hline \multirow{7}{*}{ Social Compliance Auditor } & R7 & 9 \\
\hline & R8 & 9 \\
\hline & R9 & 9 \\
\hline & R11 & 8 \\
\hline & R12 & 8 \\
\hline & R13 & 8 \\
\hline & R14 & 5 \\
\hline
\end{tabular}

\subsection{Results}

The expert respondents suggested numerous actions to provide minimal adherence to the eight focal labor standards in apparel factories, specifically within Bangladesh. These actions are classified into four general categories: onsite personnel, education and training, policies and procedures and factory planning and operations, which include a diverse range of cost-bearing actions (Table 2). The unique actions consistently suggested among the auditor sample are provided in the following sections according to each standard.

The respondents were relatively consistent in their selection of minimum cost-bearing actions required to enforce no forced labor in factories. All respondents recommended an onsite social compliance officer as well as ongoing awareness training regarding forced labor practices for workers, managers, and owners. Likewise, the majority of respondents $(93 \%)$ indicated that enforcement of accurate compensation and overtime accounting aids in controlling forced labor practices. Additional actions selected by the majority of auditors include: establishing and communicating an explicit forced labor policy to workers, managers and owners (80\%), establish a grievance mechanism for workers $(73 \%)$, provide a dedicated production planner $(73 \%)$ and implement efficient production planning procedures (73\%). Overall, the auditors primarily suggested actions related to the provision of personnel, development and enforcement of policies, education of factory stakeholders and improvements in production efficiency to address forced labor.

To address child labor practices, auditors unanimously indicated two cost-bearing actions related to personnel: provide a dedicated social compliance auditor as well as a dedicated health professional onsite. All respondents also suggested providing an onsite 
medical facility, along with implementing policies that enforce explicit age limits for recruitment. Additional actions selected by the majority of respondents include: establishing and communicating a no child labor policy to workers, managers and owners $(87 \%)$ and providing training for recruiters to avoid child labor $(73 \%)$.

Table 2. Frequency of Actions Cited among Respondents by Labor Rights Standard ( $n=15)$.

\begin{tabular}{|c|c|c|c|c|c|c|c|c|c|}
\hline \multirow{2}{*}{ Category } & \multirow{2}{*}{$\begin{array}{l}\text { Minimum Action Required to } \\
\text { Implement Standard }\end{array}$} & \multicolumn{8}{|c|}{ Standards } \\
\hline & & FL & CL & $\mathrm{C}$ & WH & FOA & H\&S & ND & DP \\
\hline \multirow{5}{*}{$\begin{array}{l}\text { Onsite } \\
\text { Personnel }\end{array}$} & Provide dedicated social compliance officer & 15 & 15 & 15 & 15 & 15 & & 15 & 15 \\
\hline & Provide dedicated production planner & 11 & & 11 & 11 & & & & \\
\hline & Provide dedicated health care professional & & 15 & & & & 15 & & \\
\hline & $\begin{array}{l}\text { Provide dedicated occupational health and safety } \\
\text { (OHS) officer }\end{array}$ & & & & & & 15 & & \\
\hline & Provide dedicated maintenance officer & & & & & & 15 & & \\
\hline \multirow{2}{*}{$\begin{array}{l}\text { Education } \\
\text { and } \\
\text { Training }\end{array}$} & $\begin{array}{l}\text { Provide ongoing awareness training focused on } \\
\text { specific standards and related company policy } \\
\text { (workers, managers, compliance personnel) }\end{array}$ & 15 & & 15 & 15 & 15 & 15 & 15 & 15 \\
\hline & $\begin{array}{l}\text { Provide recruitment training to relevant } \\
\text { factory personnel }\end{array}$ & & 11 & & & & & & \\
\hline \multirow{6}{*}{$\begin{array}{l}\text { Policies and } \\
\text { Procedures }\end{array}$} & $\begin{array}{l}\text { Establish standards specific policy and effectively } \\
\text { communicate policy and procedures (workers, } \\
\text { managers, compliance personnel) }\end{array}$ & 12 & 13 & & & 15 & 15 & 13 & 13 \\
\hline & $\begin{array}{l}\text { Establish recruitment policy with age } \\
\text { verification procedure }\end{array}$ & & 15 & & & & & & \\
\hline & Implement an effective grievance mechanism & 11 & & 15 & 12 & 15 & & 15 & 15 \\
\hline & $\begin{array}{l}\text { Implement accurate compensation and overtime } \\
\text { accounting procedures }\end{array}$ & 14 & & & & & & & \\
\hline & Establish worker performance appraisals & & & & & & & 3 & \\
\hline & $\begin{array}{l}\text { Implement skills-based approach to establish } \\
\text { worker pay }\end{array}$ & & & 15 & & & & & \\
\hline \multirow{11}{*}{$\begin{array}{l}\text { Factory } \\
\text { Planning } \\
\text { and } \\
\text { Operations }\end{array}$} & $\begin{array}{l}\text { Implement efficient production } \\
\text { planning process(es) }\end{array}$ & 11 & & 3 & 13 & & & & \\
\hline & Provide personal protective equipment (PPE) & & & & & & 15 & & \\
\hline & $\begin{array}{c}\text { Provide clean drinking water, cafeteria, toilets, and } \\
\text { other basic amenities }\end{array}$ & & & & & & 15 & & \\
\hline & Provide onsite medical facility & & 15 & & & & 15 & & \\
\hline & $\begin{array}{l}\text { Payment of legal minimum wage, overtime, legal } \\
\text { benefits, and elimination of unauthorized } \\
\text { deductions }\end{array}$ & & & 15 & 15 & & & & \\
\hline & $\begin{array}{l}\text { Implement reliable and fair worker } \\
\text { attendance accounting }\end{array}$ & & & 15 & 15 & & & & \\
\hline & $\begin{array}{c}\text { Ensure factory compliance with Bangladesh } \\
\text { Accord and Alliance fire, electrical, and building } \\
\text { safety standard }\end{array}$ & & & & & & 15 & & \\
\hline & Provide service book to the workers & & & & 11 & & & & \\
\hline & $\begin{array}{l}\text { Establish worker recruitment planning based on } \\
\text { production planning }\end{array}$ & & 4 & & & & & & \\
\hline & $\begin{array}{l}\text { Provide digital wage payment to workers } \\
\text { connected to a digital attendance system }\end{array}$ & & & 1 & 1 & & & & \\
\hline & $\begin{array}{l}\text { Provide adequate resources to manage } \\
\text { workers' union }\end{array}$ & & & & & 1 & & & \\
\hline
\end{tabular}

Note: $\mathrm{FL}=$ Forced Labor, $\mathrm{CL}=$ Child Labor, $\mathrm{C}=$ Compensation, $\mathrm{WH}=$ Working Hours, FOA $=$ Freedom of Association, $\mathrm{H} \& \mathrm{~S}=\mathrm{Health}$ and Safety, ND = Non-discrimination and DP = Disciplinary Actions.

In terms of compensation, respondents consistently recommended providing an onsite social compliance officer, providing awareness training on compensation policy, establishing an effective grievance mechanism, and establishing payment systems based on worker skills. The respondents also unanimously indicated that enforcement of the minimum wage, overtime payment, legal benefits and implementation of a worker attendance system 
are needed for minimum compliance to compensation standards. Additionally, most respondents recognized a need for production planning personnel $(73 \%)$, while fewer $(20 \%)$ suggested implementation of efficient planning processes.

For minimum cost-related actions required to enforce working hours standards in factories, respondents unanimously indicated a need for an onsite compliance officer and production planner, payment of the legal minimum wage, provision of overtime and benefits as well as implementation of a worker attendance system. Additional actions suggested by the majority of respondents to meet working hours standards include: implementation of efficient production planning $(86 \%)$, provision of a grievance mechanism for workers $(80 \%)$, provision of a service book $(73 \%)$ and an onsite production planner $(73 \%)$. In regard to freedom of association, respondents unanimously indicated provision of an onsite social compliance officer, FOA awareness training for workers, managers and owners, and effective communication of FOA policy. These are costs that must ultimately be folded into the overhead costs of operating the factory.

Recommended actions related to health and safety suggested the highest degree of agreement among the auditors. All respondents suggested onsite access to a health care professional, access to an occupational health and safety (OHS) officer, and maintenance personnel. Further, the entire sample indicated a need for health and safety related awareness training, effective communication of relevant policies and provision of personal protection equipment (PPE). Again, all respondents indicated that compliance with the Accord and Alliances also constitutes a minimum action to meet health and safety standards; note that both initiatives were active at the beginning of data collection but have since ended for the most part. Here again, these investments are likely to increase overhead costs associated with the factory operational costs.

To support freedom of association and collective bargaining rights, the auditors unanimously suggested provision of an onsite social compliance officer, development and communication of a clear freedom of association policy, training for factory workers, managers and owners and establishment of a grievance mechanism. Only a single respondent suggested that the factory should commit resources to directly support workers' unions.

To enforce non-discrimination, all respondents indicated a need for an onsite social compliance officer, along with awareness training and implementation of an effective grievance mechanism for workers. Additionally, most expert respondents (86\%) also recommend establishing and communicating a clear non-discrimination policy at the factory. Similarly, the experts suggested a narrow range of actions to enforce disciplinary practices with unanimous agreement for providing an onsite social compliance officer, providing awareness training to all employees and establishing effective grievance mechanism. Likewise, the majority of the respondents $(86 \%)$ also recommended establishing and communicating a clear non-discrimination policy at the factory.

\subsection{Discussion and Implications}

The findings suggest three general directions that offer insight into the resources required for labor standards enforcement in apparel factories. Primarily, the results indicated a number of actions that addressed at least seven of the eight labor standards, thereby indicating that these actions can serve to improve compliance across multiple areas in a given factory. In addition, the results suggest several unique actions for enforcing select standards which can be useful for factories with persistent violations in one or more of these areas. Finally, the findings illustrate the interdependence of enforcement among labor standards that is widely suggested in previous research, underscoring the importance of a systematic approach to compliance in factories.

On the whole, respondents consistently selected the following actions to address nearly all the labor standards, including providing an onsite compliance auditor, providing awareness training and establishing a grievance mechanism for workers. Additionally, the development and communication of policies surrounding each standard was widely recommended among the respondents. Therefore, these actions likely represent focal areas 
for factories to concentrate improvements that can impact overall factory compliance. In practice, many of these actions can be addressed by the presence of an onsite compliance officer who develops and communicates policy, provides ongoing training, and establishes and monitors a grievance process for workers. From this perspective, multiple cost-bearing actions would be covered by the personnel investment alone. The costs of investing in a compliance officer to enforce these policies will ultimately increase the overhead costs of operating the factory.

In some cases, a particular labor standard enforcement elicited unique suggestions. The actions suggested for health and safety compliance stand out as the most distinct among the nine standards. In addition to the sheer number of actions suggested for health and safety, the consistency with which the auditors recommended these actions was nearly unanimous. The need for committed human resources in factories to address this standard was pronounced, with respondents indicating a need for an onsite health care professional, an occupational health and safety professional and an onsite maintenance worker for building safety. Further, an onsite medical facility, provision of personal protective equipment and clean facilities with access to drinking water, restrooms and food were also recommended by all respondents to address this standard, thereby illustrating the potential breath of actions and considerable capital required to ensure compliance in this particular area. Past research notes the prevalence of non-compliance with health and safety standards among Asian apparel factories, thus underscoring the particular challenge associated with protecting workers in this context [58]. Adherence to these requirements will ultimately increase the overhead and personnel costs of operating the factory, a cost which brands must be prepared to cover if they wish to source from a sustainable supplier.

Three unique actions associated with recruitment were suggested for curtailing child labor: establish an age verification procedure, provide recruitment training to appropriate personnel and, to a lesser extent, integrate recruitment and production planning to reduce the need for unplanned labor. A need to formalize documentation processes during the hiring process, including age verification, has been repeatedly called for by labor rights advocates in recent years $[59,60]$.

The results also reflect the interrelated nature of labor rights violations within a factory environment. For example, the action to implement efficient planning processes in factories was selected by respondents for addressing forced labor, compensation, and working hours in varying degrees. Therefore, efforts to improve an existing compliance shortfall for a single standard may prevent failures associated with related standards; indeed, past research demonstrates this dynamic in different contexts. Human Rights Watch (2015) attributes forced labor and physical abuse as outcomes of poor production planning [61], while past empirical research reports similar linkages between labor violation contexts, including the likelihood that subcontracting practices among first-tier factories increase the incidence of child labor in shadow factories that operate without public or private oversight [42,62].

The actions identified as critical by the experts provide a solid playbook for factories and brands to collaborate and focus on improvements in operational policies and procedures on the factory flow. Together, these actions create an improved environment supporting increased transparency and safety for factory workers, managers and owners. The actions require a commitment to new management processes and resources that inform workers of their rights, and provide a mechanism for systematically enforcing these rights through formal documentation, thereby providing a safe channel for worker grievances and feedback. These results are therefore consistent with prior research that advocates process management interventions for the prevention of labor violations across a range of areas including child labor [61], compensation and working hours violations [42,63], working hours [64], discrimination [65-67], disciplinary practices [58,68,69], as well as health and safety [70]. Our contribution here is to combine them into a single meaningful taxonomy that can serve as the basis for further empirical investigation and which delves into the interrelationships that may exist among them. 


\section{Limitations and Future Research}

The findings of this research serve to identify cost-bearing actions required to implement labor rights standards in an apparel production factory. This research does not attempt to quantify these activities, something which requires a unique research approach and greater access to proprietary information. Our goal was to provide insights regarding those critical actions required to address labor rights without identifying the actual costs of these actions. Contextual factors, including domestic conditions in the country of manufacture as well as trade policy and supply chain operations, should be taken into account when quantifying the actions articulated in this research.

Although the expert respondents in this study are highly experienced in performing audits in Asia, their exposure is primarily limited to export oriented first-tier factories in both home and host country which are less likely to engage in extensive labor violations compared to non-transparent second and third-tier factories. Therefore, their expert opinions should not be extended beyond the domain of first-tier factories without careful consideration of the application context. Further, the experts' auditing experience encompasses a number of Asian countries and should therefore be applied with caution outside of this regional context.

The Delphi approach employed in the study is effective for building consensus among a group of experts focused on this topic of interest. Though this approach is efficient for constructing an integrated understanding of otherwise opaque phenomena, in the context of this research, the conditions leading to the selections of these actions are not articulated. A deeper understanding of the barriers to implementing these labor standards in vulnerable environments from diverse stakeholder perspectives is required for effective labor rights implementation. For example, Anner (2017) points out the difficulty of a functioning trade union to succeed in countries without a democratic government, indicating that freedom of association is impacted by the culture and is therefore unlikely to be controlled by factory management [42]. As a result, the auditors in this study are probably not well-equipped to generate deep insights about freedom of association due to their audit experience in the labor repressive regime. Additionally, the influence of external monitoring bodies (e.g., brands, third-party organizations) likely impact the manner that factories enforce labor standards and may conflict with the recommended actions reported in this research. We recognize that the application of a Delphi study research design is appropriate for delving into the content of social compliance regulations, and understand the critical elements that represent cost increases. These findings should be validated in the future through broader empirical studies; for instance, future studies could explore the development of these measures, and the associated cost impacts on apparel prices, and the relative willingness of brands to cover these costs when sourcing from low-cost apparel factories.

Several of the actions suggested by the experts have presented challenges for implementation in the past. For example, though Curtze and Steve (2017) strongly advocate for providing a grievance system for factory workers, they stress the importance of designing a user-friendly system for workers with limited literacy [71]. Lack of worker literacy can impact a number of recommended actions and should therefore be weighed when preparing educational materials. As mentioned previously, cultural barriers to freedom of association in Bangladesh complicate the implementation of actions related to this particular standard [10].

For sourcing and supply chain managers, this study provides a starting point for considering the actions required to ensure minimum compliance with labor standards in an apparel factory; this provides a basis for estimating the cost of labor complaint production from a content standpoint. Global apparel brands are frequently accused of demanding excessively low costs from factories, which ultimately leads to persistent labor rights violations. This study provides initial insight into the minimum components required to estimate a more equitable price under improved labor conditions.

Future research into labor standards implementation in Bangladesh and additional low-cost apparel production countries should focus on designing initiatives to improve 
production planning in apparel factories, ways to build awareness around labor standards among factory personnel at all levels, and establishing safe and effective channels of communication between workers and external stakeholders for increased transparency. Innovative approaches to these efforts using cost efficient technology (i.e., digital record keeping and training programs) can potentially reduce the cost of these actions as well as the prevalence of labor violations. We also recognize the need for broader studies on the interaction of factory costs and brand managers' willingness to cover the cost of compliance.

Author Contributions: Conceptualization, R.H. (Rejaul Hasan), M.M. and R.H. (Robert Handfield).; methodology, R.H. (Rejaul Hasan).; software, N/N/AA; validation, R.H. (Rejaul Hasan) and M.M.; formal analysis, R.H. (Rejaul Hasan); investigation, R.H. (Rejaul Hasan); resources, R.H. (Rejaul Hasan); data curation, R.H. (Rejaul Hasan).; writing—original draft preparation, R.H. (Rejaul Hasan), M.M., and R.H. (Robert Handfield); writing—review and editing, R.H. (Rejaul Hasan), M.M., and R.H. (Robert Handfield); visualization, R.H. (Rejaul Hasan); supervision, M.M.and R.H. (Robert Handfield); project administration, M.M.; funding acquisition, N/A. All authors have read and agreed to the published version of the manuscript.

Funding: This research received no external funding.

Institutional Review Board Statement: The study was conducted according to the guidelines of the Declaration of Helsinki, and approved by the Institutional Review Board (or Ethics Committee) of North Carolina State University (2018).

Informed Consent Statement: Informed consent was obtained from all subjects involved in the study.

Data Availability Statement: Not applicable.

Conflicts of Interest: The authors declare no conflict of interest.

\section{References}

1. Elkington, J. Cannibals with Forks: The Triple Bottom Line of the 21st Century; New Society Publishers: Stoney Creek, ON, Canada, 1998.

2. Quarshie, A.; Salmi, A.; Leuschner, R. Sustainability and corporate social responsibility in supply chains: The state of research in supply chain management and business ethics journals. J. Purch. Supply Manag. 2016, 22, 82-97. [CrossRef]

3. Seuring, S.; Müller, M. From a literature review to a conceptual framework for sustainable supply chain management. J. Clean. Prod. 2008, 16, 1699-1710. [CrossRef]

4. Gimenez, C.; Sierra, V.; Rodon, J. Sustainable operations: Their impact on the triple bottom line. Int. J. Prod. Econ. 2012, 140, 149-159. [CrossRef]

5. Touboulic, A.; Walker, H. Theories in sustainable supply chain management: A structured literature review. Int. J. Phys. Distrib. Logist. Manag. 2015, 45, 16-42. [CrossRef]

6. Zorzini, M.; Hendry, L.; Huq, F.A.; Stevenson, M. Socially responsible sourcing: Reviewing the literature and its use of theory. Int. J. Oper. Prod. Manag. 2015, 35, 60-109. [CrossRef]

7. Köksal, D.; Strähle, J.; Müller, M.; Freise, M. Social Sustainable Supply Chain Management in the Textile and Apparel Industry-A Literature Review. Sustainability 2017, 9, 100. [CrossRef]

8. Awaysheh, A.; Klassen, R. The impact of supply chain structure on the use of supplier socially responsible practices. Int. J. Oper. Prod. Manag. 2010, 30, 1246-1268. [CrossRef]

9. Stigzelius, I.; Mark-Herbert, C. Tailoring corporate responsibility to suppliers: Managing SA8000 in Indian garment manufacturing. Scand. J. Manag. 2009, 25, 46-56. [CrossRef]

10. Anner, M.; Bair, J.; Blasi, J. Toward joint liability in global supply chains: Addressing the root causes of labor violations in international subcontracting networks. Comp. Labor Law Policy J. 2013, 35, 1.

11. Better Work Publications. Available online: https://betterwork.org/our-impact/publications/ (accessed on 25 September 2020).

12. Eisenbraun, J.; Cohen, K.; Brown, D. Occupational Safety and Health Conditions in the Apparel Factories: Worker Perceptions and the Role of Management Systems; ILO: Geneva, Switzerland, 2015.

13. Miller, D.; Williams, P. What price a living wage? Implementation issues in the quest for decent wages in the global apparel sector. Glob. Soc. Policy 2009, 9, 99-125. [CrossRef]

14. Ford, M.; Gillan, M. In search of a living wage in Southeast Asia. Empl. Relat. 2017, 39, 903-914. [CrossRef]

15. Toward Fair Compensation in Bangladesh: Insights on Closing the Wage Gap; Fair Labor Association: Washington, DC, USA, 2018.

16. Climbing the Ladder to Living Wages, an Update on FWF's Living Wage Research; Fair Wear Foundation: Amsterdam, The Netherlands, 2012. 
17. Pruett, D. Looking for a Quick Fix: How Weak Social Auditing is Keeping Workers in Sweatshops; Clean Clothes Campaign: Amsterdam, The Netherlands, 2005.

18. Mattioda, R.A.; Mazzi, A.; Canciglieri, O.; Scipioni, A. Determining the principal references of the social life cycle assessment of products. Int. J. Life Cycle Assess. 2015, 20, 1155-1165. [CrossRef]

19. Van der Velden, N.M.; Vogtländer, J.G. Monetisation of external socio-economic costs of industrial production: A social-LCA-based case of clothing production. J. Clean. Prod. 2017, 153, 320-330. [CrossRef]

20. ILO Conventions and Recommendations. ECD. 2018. Available online: https://www.ilo.org/global/standards/introduction-tointernational-labour-standards/conventions-and-recommendations/lang--en/index.htm (accessed on 15 October 2021).

21. OECD. Available online: http://mneguidelines.oecd.org/OECD-Due-Diligence-Guidance-for-Responsible-Business-Conduct. pdf (accessed on 15 October 2021).

22. OECD. Available online: https://www.oecd.org/industry/inv/mne/ (accessed on 15 October 2021).

23. UN Global Compact. Available online: https://www.unglobalcompact.org/what-is-gc/mission/principles (accessed on 15 October 2021).

24. O'Rourke, D. Outsourcing Regulation: Analyzing Nongovernmental Systems of Labor Standards and Monitoring. Policy Stud. J. 2003, 31, 1-29. [CrossRef]

25. Finnegan, B. Responsibility Outsourced: Social Audits, Workplace Certification and Twenty Years of Failure to Protect Worker Rights; Report; The American Federation of Labor-Congress of Industrial Organizations (AFL-CIO): Washington, DC, USA, 2013; Volume 30, pp. 7-9.

26. Locke, R.M.; Qin, F.; Brause, A. Does Monitoring Improve Labor Standards? Lessons from Nike. ILR Rev. 2007, 61, 3-31. [CrossRef]

27. The Work Bank. Company Codes of Conduct and International Standards: An Analytical Comparison. 2003. Available online: https:/ / documents1.worldbank.org/curated/en/416281468096001385/pdf/346620v10CompanyCodesofConduct.pdf (accessed on 15 October 2021).

28. Locke, R.; Amengual, M.; Mangla, A. Virtue out of Necessity? Compliance, Commitment, and the Improvement of Labor Conditions in Global Supply Chains. Politics Soc. 2009, 37, 319-351. [CrossRef]

29. ILO. Sectoral Studies on Decent Work in Global Supply Chains. 2015. Available online: https://www.ilo.org/wcmsp5/groups/ public/---ed_dialogue/---sector/documents/publication/wcms_467295.pdf (accessed on 15 October 2021).

30. Ross, R.J. The Twilight of CSR, Life and Death Illuminated by Fire. In Achieving Workers' Rights in the Global Economy; Appelbaum, R.P., Lichtenstein, N., Eds.; Cornell University: Ithaca, NY, USA, 2016; pp. 77-90.

31. Nova, S.; Wegemer, C. 1. Outsourcing Horror: Why Apparel Workers Are Still Dying, One Hundred Years after Triangle Shirtwaist. In Achieving Workers' Rights in the Global Economy; Cornell University Press: Ithaca, NY, USA, 2017; pp. 17-31.

32. O'Rourke, D. Smoke from a Hired Gun: A Critique of Nike's Labor and Environmental Auditing; Transnational Resource and Action Center: San Francisco, CA, USA, 1997.

33. Barrientos, S.; Smith, S. Do workers benefit from ethical trade? Assessing codes of labour practice in global production systems. Third World Q. 2007, 28, 713-729. [CrossRef]

34. Short, J.L.; Toffel, M.W.; Hugill, A.R. Monitoring global supply chains. Strat. Manag. J. 2016, 37, 1878-1897. [CrossRef]

35. Palmarozzo, A.; Short, J.; Toffel, M. Auditor Independence and Outsourcing: Aligning Incentives to Mitigate Shilling and Shirking. Acad. Manag. Proc. 2021, 2021. [CrossRef]

36. Walsh, D.; Greenhouse, S. Certified safe, a factory in Karachi still quickly burned. New York Times, 7 December 2012.

37. Walsh, D.; Greenhouse, S. Inspectors certified pakistani factory as safe before disaster. New York Times, 19 December 2012.

38. Toffel, M.W.; Short, J.; Ouellet, M. Codes in context: How states, markets, and civil society shape adherence to global labor standards. Regul. Gov. 2015, 9, 205-223. [CrossRef]

39. Baumann-Pauly, D.; Labowitz, S.; Banerjee, N. Closing Governance Gaps in Bangladesh's Garment Industry-The Power and Limitations of Private Governance Schemes. SSRN Electron. J. 2015. [CrossRef]

40. Alamgir, F.; Banerjee, S.B. Contested compliance regimes in global production networks: Insights from the Bangladesh garment industry. Hum. Relations 2018, 72, 272-297. [CrossRef]

41. Siddiqui, J.; Uddin, S. Human rights disasters, corporate accountability and the state: Lessons learned from Rana Plaza. Account. Audit. Account. J. 2016, 29, 679-704. [CrossRef]

42. Anner, M. Wildcat Strikes and Better Work Bipartite Committees in Vietnam: Toward an Elect, Represent, Protect and Empower Framework; International Labour Office: Geneva, Switzerland, 2017.

43. Anner, M.; Hossain, J. Multinational corporations and economic inequality in the Global South: Causes, consequences, and countermeasures. In Proceedings of the Global Labour University Conference, Berlin, Germany, 15-17 May 2014.

44. Anner, M. Binding power: The sourcing squeeze, workers' rights, and building safety in Bangladesh since Rana Plaza. Center for Global Workers' Rights, Penn State University. 2018. Available online: https://ler.la.psu.edu/gwr/documents/CGWR201 7ResearchReportBindingPower.pdf (accessed on 20 October 2021).

45. Popp, A.; Ruckman, J.; Rowe, H. Quality in international clothing supply chains: Cost versus quality. J. Fash. Mark. Manag. Int. J. 2001, 5, 275-288. [CrossRef]

46. Yardley, J. Horrific fire revealed a gap in safety for global brands. New York Times, 7 December 2012.

47. Clifford, S.; Greenhouse, S. Fast and flawed inspections of factories abroad. New York Times, 1 September 2013. 
48. Locke, R.M. Response to Dietlind Stolle's review of The Promise and Limits of Private Power: Promoting Labor Standards in a Global Economy. Perspect. Politics 2016, 14, 523. [CrossRef]

49. Hassan, R.; Moore, M.; Handfield, R. Addressing Social Issues in Commodity Markets: Using Cost Modeling as an Enabler of Public Policy in the Bangladeshi Apparel Industry. J. Supply Chain Manag. 2020, 56, 25-44. [CrossRef]

50. Leveraging Desperation: Apparel Brands' Purchasing Practices during Covid-19. Available online: https://www.workersrights org/wp-content/uploads/2020/10/Leveraging-Desperation.pdf (accessed on 24 October 2021).

51. Adler, M.; Ziglio, E. Gazing into the Oracle: The Delphi Method and Its Application to Social Policy and Public Health; Jessica Kingsley Publishers: London, UK, 1996.

52. Delbecq, A.L.; Van de Ven, A.H.; Gustafson, D.H. Group Techniques for Program Planning: A Guide to Nominal Group and Delphi Processes; Scott Foresman: Glenview, IL, USA, 1975.

53. Linstone, H.A.; Turoff, M. (Eds.) The Delphi Method; Addison-Wesley: Boston, MA, USA, 1975; pp. 3-12.

54. Skulmoski, G.; Hartman, F. The Delphi method: Researching what does not exist (yet). In Proceedings of the International Research Network on Organization by Projects, IRNOP V Conference, Renesse, The Netherlands, 29-31 May 2002.

55. Skulmoski, G.; Hartman, F.T.; Krahn, J. The Delphi Method for Graduate Research. J. Inf. Technol. Educ. Res. 2007, 6, 1-21. [CrossRef]

56. BGMEA. Trade Information. Available online: https://www.bgmea.com.bd/export-performances/4 (accessed on 25 September 2021).

57. Okoli, C.; Pawlowski, S.D. The Delphi method as a research tool: An example, design considerations and applications. Inf. Manag. 2004, 42, 15-29. [CrossRef]

58. Rourke, E.L. Is There a Business Case Against Verbal Abuse? Incentive Structure, Verbal Abuse, Productivity and Profits in Garment Factories; ILO: Geneva, Switzerland, 2014.

59. Better Work Indonesia. Guidelines on the Prevention of Workplace Harassment, Guideline for Employers. 2017. Available online: https:/ / betterwork.org/wp-content/uploads/2017/10/Guidelines-on-the-Prevention-of-Workplace-Harassment_ENG3.pdf (accessed on 15 October 2021).

60. BSR. Child Labor in Myanmar's Garment Sector, Challenges and Recommendations. 2016. Available online: https://www.bsr. org/reports/BSR_Child_Labor_Myanmar_Garment_Sector_2016.pdf (accessed on 15 October 2021).

61. Human Rights Watch. "Whoever Raises their Head Suffers the Most" Workers' Rights in Bangladesh's Garment Factories. 2015. Available online: https:/ / www.hrw.org/report/2015/04/22/whoever-raises-their-head-suffers-most/workers-rightsbangladeshs-garment (accessed on 15 October 2021).

62. Overeem, P.; Theuws, M. Fact Sheet-Child Labour in the Textile \& Garment Industry, Focus on the Role of Buying Companies. 2014. Available online: https:/ / www.somo.nl/fact-sheet-child-labour-focus-on-the-role-of-buying-companies / (accessed on 15 October 2021).

63. Ji-Won Seo, J. Excessive Overtime, Workers and Productivity: Evidence and Implications for Better Work; ILO: Geneva, Switzerland, 2011.

64. Hurst, R.; Murdoch, H.; Gould, D. Changing Over Time: Tackling Supply Chain Labour Issues through Business Practice; The Impactt Overtime Project; ILO: Geneva, Switzerland, 2005.

65. Paul-Majumder, P.; Begum, A. The Gender Imbalances in the Export Oriented Garment Industry in Bangladesh; World Bank, Development Research Group/Poverty Reduction and Economic Management Network: Washington, DC, USA, 2000.

66. Nicita, A.; Razzaz, S. Who Benefits and How Much? How Gender Affects Welfare Impacts of a Booming Textile Industry; The World Bank: Washington, DC, USA, 2003.

67. Fleck, S. A Gender Perspective on Maquila Employment and Wages in Mexico. In The Economics of Gender in Mexico: Work, Family, State, and Market; The World Bank: Washington, DC, USA, 2001; p. 133.

68. Siddiqi, D.M. The Sexual Harassment of Industrial Workers: Strategies for Intervention in the Workplace and Beyond; CPD-UNFPA Publication Series Paper No. 26; Centre for Policy Dialogue: Dhaka, Bangladesh, 2003; p. 40.

69. Truskinovsky, Y.; Rubin, J.; Brown, D. Sexual Harassment in Garment Factories: Firm Structure, Organizational Culture and Incentive Systems; ILO: Geneva, Switzerland, 2014.

70. Johansson, B.; Rask, K.; Stenberg, M. Piece rates and their effects on health and safety-A literature review. Appl. Ergon. 2010, 41, 607-614. [CrossRef] [PubMed]

71. Curtze, L.; Gibbons, S. Access to Remedy-Operational Grievance Mechanisms, An Issues Paper for ETI. 2017. Available online: https:/ / www.ethicaltrade.org/sites/default/files/shared_resources/ergon_-_issues_paper_on_access_to_remedy_and_ operational_grievance_mechanims_-_revised_draft.pdf (accessed on 15 October 2021). 